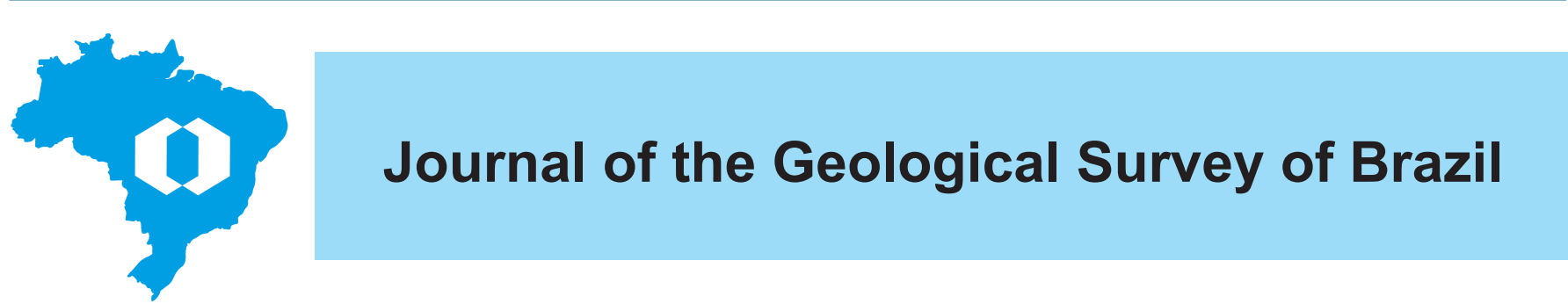

\title{
Identification of impact cratering-related similarities based on airborne geophysical data and satellite images: the Cabeça de Sapo Structure, Parnaíba Basin, Northeast Brazil
}

\author{
Adolfo Barbosa da Silva ${ }^{1 *}$, \\ ${ }^{1}$ Serviço Geológico do Brasil. Rua 148, 485 - Setor Marista, Goiânia - GO - Brazil, CEP: 74170-110
}

\section{Abstract}

This study was performed to identify and interpret airborne geophysical responses and landform features of the Cabeça de Sapo Structure (CSS), a $6 \mathrm{~km}$-diameter circular structure located in northeastern Brazil, SW of the Maranhão State, suspected of having been formed by the impact of a solid body. The application of processing techniques addressed to enhance the images from the remotely sensed data (gamma-ray spectrometry, magnetic, Sentinel 2B and ALOS PALSAR) enabled the identification of two airborne geophysical responses (ring-shaped magnetic anomaly and radiometric patterns) and five landform features ("A", "B", "C","D" and "E"). The ring-shaped magnetic anomaly is related to a $5.4 \mathrm{~km}$-diameter well-defined circular structure and the depth of its magnetic sources is estimated in $300 \mathrm{~m}$. Those sources are unknown, but they probably occur due to layers of dolerite sills. The radiometric patterns identified seem to be related to the "A" and " $\mathrm{D}$ " landform features. Feature "A" is an elevated area at the center of CSS. The radiometric response (high $e T h, e U$, and low $K$ ) at the top of this area possibly reflects the weathering effect, while the radiometric response (high $K$ and low $e T h, e U$ ) at the hillside is possibly from the lithotypes that have supported this elevation. Feature " $D$ " is a $6 \mathrm{~km}$ - diameter circular elevated area that corresponds to the outer boundary of CSS. This boundary is characterized by increased eU counts, which may happen due to weathering-resistant mineral content (e.g. zircon) present in eolian sandstones. Features "C" and "E" are outside of CSS. The first is interpreted as plateau-shaped residual relief formed by differential erosion of basaltic rocks and sandstones and the second is interpreted as a flat-relief dominated by eolian sandstones. This flat-relief may represent the landscape that has not been affected by the formation process of CSS, while the affected internal region may be represented by feature "B". The interpretations also have revealed that CSS shows some similarities with typical features of impact structures, namely: disruption of the magnetic field by a ring-shaped magnetic anomaly; central elevation surrounded by a raised outer rim; local control of drainage and; differences in the relief pattern of internal and external parts of the structure. Those similarities reinforce the possibility of an exogenous origin of CSS, but new studies are required to confirm or refuse such possibility.
Article Information

Publication type: Research paper

Received 16 March 2020

Accepted 19 July 2020

Online pub. 26 August 2020

Editor(s): David Castro

\section{Keywords:}

Circular structures;

Ring-shaped magnetic anomaly; Gamma-ray spectrometry; Landforms.

\section{${ }^{*}$ Corresponding author} Adolfo Barbosa da Silva E-mail address: adolfo.barbosa@cprm.gov.br

\section{Introduction}

Impact structures are characterized by a circular form and evidence of intense, localized, near-surface structural disturbance, and brecciation (Grieve 1987). The most two common kinds of impact structures on Earth's surface are: simple structures - consisted of a bowl-shaped depression with a structurally uplifted ring area and; complex structures - characterized by a raised central area surrounded by an annular depression, with the outer ring being cut by normal faults (Osinski and Pierazzo 2013).

Currently, 190 impact structures have been discovered on Earth, 7 of them located in domains of Brazilian intracratonic basins (Fig. 1a) and 3 (Serra da Cangalha, Riachão Ring and Santa Marta) occur in Parnaíba Basin (PNB) (EID 2019; Crósta et al. 2018; Crósta and Vasconcelos 2013; Dietz and French 1973; Maziviero et al. 2013a; Kenkmann et al. 2011; Oliveira et al. 2014). In addition to these, there are other possible structures, whose origin by an impact is still suggested, such as São Miguel do Tapúio structure (Martins et al. 2016; Vasconcelos et al. 2010) and, more recently, Cabeça de Sapo structure (CSS). The latter is the focus of this paper.

The CSS is located in northeastern Brazil, $85 \mathrm{~km}$ and 130 $\mathrm{km}$ western from the Riachão Ring and Serra da Cangalha impact structures, respectively, at SW of the Maranhão State (Fig. 1b). Geological mapping studies coordinated by Klein 
and Sousa (2012) identified the CSS and characterized it as a circular structure. Subsequently, Brenha (2013) and Oliveira (2017) suggested the impact origin of the CSS in their respective studies. However, the origin by the impact of the CSS is still questionable, because, until now, there is no researches have reported definitive evidence of shock metamorphism. Furthermore, studies on the interpretation of the main CSS structural features based on the analysis of remotely sensed images like airborne geophysical and satellite images have not been published yet. Such studies are important because, since the CSS is located in a remote region of a large sedimentary basin, direct observation methods can be difficult, either because some features of the structure may be buried and/or eroded, or due to difficulties in the logistics of field research. In order to mitigate those difficulties, processing techniques can be applied to enhance the images collected by remote sensors. The interpretation of these highlighted images may reveal new insights about the lithology and structure of the CSS, thus constituting a guide for further studies in the region, as well as proving a wide view of the CSS. Within this context, based on digital processing of airborne geophysical data (gammaray spectrometry and magnetic) and satellite images (Sentinel

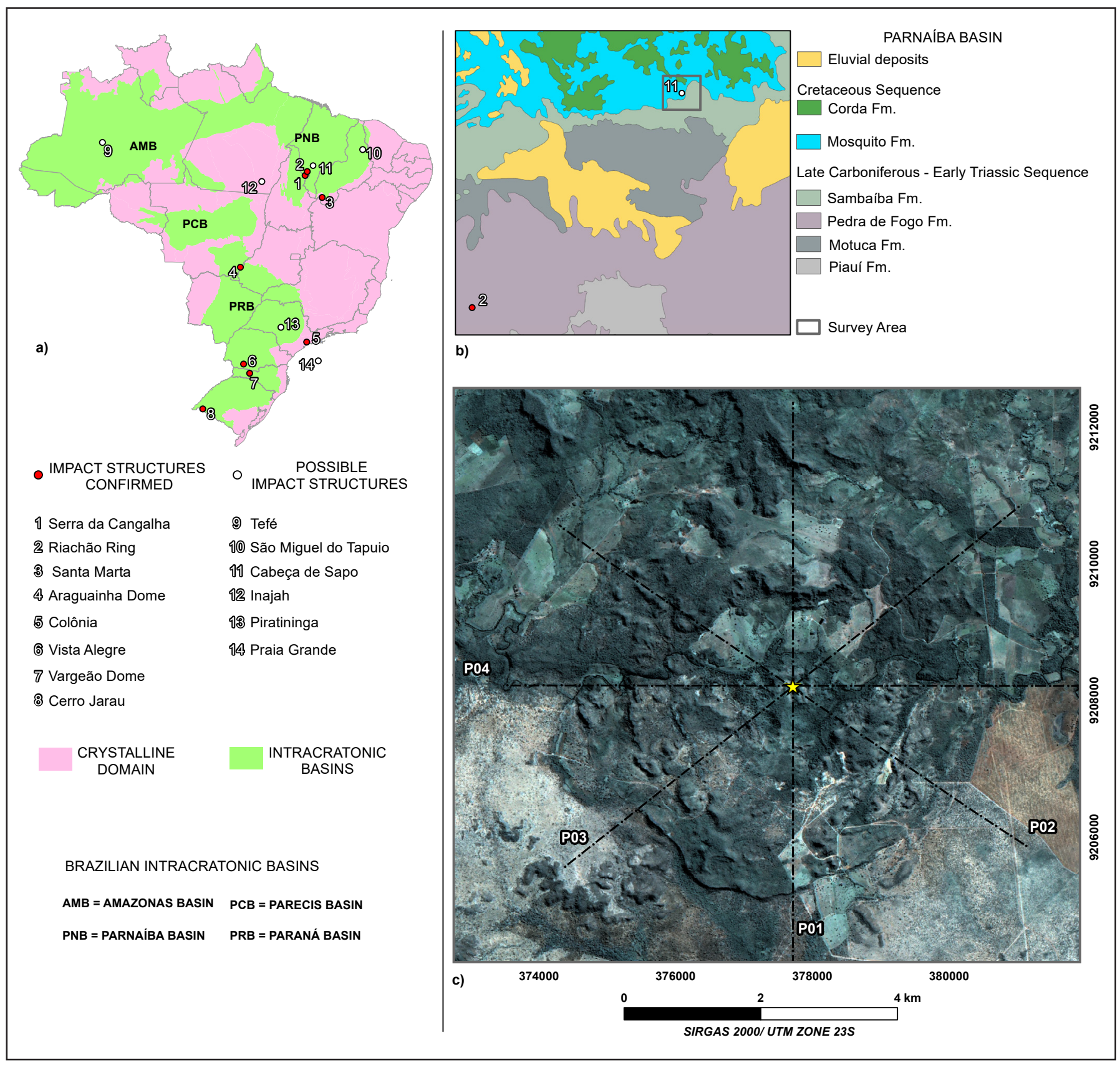

FIGURE 1. Location of the study area. a) Impact structures (confirmed and possible) in Brazil. b) Geological map of the survey area (square) and its surroundings. c) c) Satellite image of the survey area. The image was acquired by Regular Multispectral (MUX) and Panchromatic (PAN) Cameras onboard China-Brazil Earth Resource Satellite (CBERS 04) on 07/07/2019, orbit/point 158/108. The image is an RGB composition of bands 7, 6, and 5, which have been sharpened with the panchromatic band (band 01). The dashed lines P01 to P04 correspond to the location of the profiles described in the text. The yellow star corresponds to the location of the CSS central area. 
2B and ALOS PALSAR), the present work aimed to interpret airborne geophysical responses and landform features on the CSS, based on available geological information. From this interpretation, some similarities between the CSS and impact structures typical features were pointed out. It is believed that the results reported here can stimulate the development of new researches in the CSS.

\section{Geological Setting}

The PNB (formerly known as the Maranhão basin) has a circular shape, with ca. $600,000 \mathrm{~km}^{2}$, covering part of Piauí, Maranhão, Tocantins, Pará, Ceará and Bahia States (Góes and Feijó 1994). The basement consists of a complex framework that would have resulted from a collision of at least three large crustal blocks (Amazonian, Parnaíba, and Borborema) during the final consolidation phase of the Western Gondwana continent (Soares et al. 2018; Brito Neves 2002). After the Brasiliano orogenesis, extension processes resulting from the thermal contraction of the lithosphere reactivated brittle structures along old shear zones associated with the Transbrasiliano Lineament, initially forming a set of rift-type basins (Jaibaras, Cococi, São Julião, and others) that later would have aborted and suffered slow thermal subsidence controlled by failures, allowing the deposition of ca. $3.5 \mathrm{~km}$ of sedimentary rocks (Brito Neves et al. 1984; Cunha et al. 2017; Castro et al. 2016; Daly et al. 2014; Oliveira and Mohriak, 2003; Pedrosa Jr et al. 2017; Spisila et al. 2014). The PNB sedimentary column is divided into five sequences (Silurian Sequence or Serra Grande Group, Mesodevonian - Eocarboniferous or Canindé Group, Neocarbonifera Eotriassica or Balsas Group, Jurassic Sequences, and Cretaceous Sequence) with predominantly siliciclastic rocks, occurring subordinately limestone, anhydrite, and silex, in addition to diabase and basalts of the Mosquito and Sardinha Formations (Góes and Feijó 1994; Vaz et al. 2007).

According to the geological maps published by Lima and Leite (1977) and Klein and Sousa (2012) (Fig. 1b), the southern portion of the survey area is dominated by Neocarboniferous Sequence - Eotriassica eolian sandstones (Sambaíba Formation), while in the northern portion there are tholeiitic basalt flows (Mosquito Formation) and, over these, some Cretaceous Sequence sandstones (Cord Formation) occurring locally.

The Sambaíba Formation is composed of reddish, pinkish, and whitish, fine- to medium-grained, sub-argillaceous to subreddened eolian sandstones, with abundant cross-bedding, deposited in a desert environment with a fluvial contribution (Aguiar 1971; Lima and Leite 1977; Vaz et al. 2007). In general, the eolian sandstones of Sambaíba Formation have low scintillometric values (15 - $25 \mathrm{cps}$ ) and low magnetic susceptibility (Lima and Leite 1977; Mocitaiba et al. 2017).

The low Ti tholeiitic basalts of Mosquito Formation are composed basically of pyroxenes, plagioclases, Fe-Ti oxides, volcanic glasses, and vesicles/amygdalae filled with calcite, quartz or zeolites (Baski and Archibald 1997; Oliveira et al. 2018). According to previous studies, the Mosquito Formation basalts are aged between 189 - $200 \mathrm{Ma}$ and are correlated with the magmatism that resulted in the breaking of the Pangea continent (Baski and Archibald 1997; Fodor et al. 1990; Merle et al. 2011). In terms of airborne geophysical responses, the Mosquito Formation igneous rocks have generated a low gamma-ray spectrometric response and magnetic anomalies of $60 \mathrm{nT}$ with an elongated shape and rugged appearance (Correia 2019; Mocitaiba et al. 2017). The basalts are superimposed by sandstones (Cordas Formation). Such rocks are red, brownreddish, very thin/fine, and medium sandstones, rich in iron oxides and zeolites, deposited in desert environments (Aguiar 1971; Lima and Leite 1977; Vaz et al. 2007).

Both Brenha (2013) and Oliveira (2017) interpreted CSS as a complex impact structure, with a central uplifted ring (referred here as a central area - CA) and an outer ring with $6.03 \mathrm{~km}$ in diameter cut by normal faults. The authors have also identified unusual rocks, such as breccias, melted rocks, and pseudotachylite, but the shock metamorphic indicators (e.g. shatter cones, planar deformation features, diaplectic glass, high - pressure polymorphs) have not been documented. Consequently, the absence of these indicators prevents the CSS from being recognized as an impact structure, despite the morphological and petrological evidence.

\section{Methods}

The airborne geophysical data and satellite images were processed and interpreted to investigate the origin of CSS as an impact structure. Both data sets were projected for UTM coordinates, zone 23S, and SIRGAS 2000 datum. The airborne geophysical data corresponds to the magnetic and gamma-ray spectrometry data acquired and pre-processed during 2005 and 2006 by the Critical Technologies Application Foundation (Atech) and by the University of São Paulo and are the domain of the Brazilian National Agency of Petroleum, Natural Gas and Biofuels. The flight and ties spacing were $0.5 \mathrm{~km}$, in the NS direction, and $4 \mathrm{~km}$, in the EW direction, respectively. The nominal terrain clearance height was 100 $\mathrm{m}$. In the pre-processing stage, the following corrections were performed: parallax corrections, removal of daytime variation, removal of the International Geomagnetic Reference Field (IGRF), levelling and micro-levelling for magnetic data and; dead time, background removal (aircraft, cosmic and radon), height and Compton effect and conversion to elemental concentrations for gamma-ray spectrometric data (Marques et al. 2006). The post-processing step performed in this study basically consisted of interpolating data and enhancement of the images using Geosoft's Oasis MontajTM 9.6 software.

The magnetic data were interpolated by the $\mathrm{Bi}$-directional method (125 m cell size), while the gamma-ray spectrometry data were interpolated by the inverse distance weighted method (125 $\mathrm{m}$ cell size and $500 \mathrm{~m}$ search radius). The interpolation process of geophysics data generated the Anomalous Magnetic Field (AMF) and radioelement concentrations ( $\mathrm{K}$, $e T h$, and $e U$ ) grids.

To highlight the contrast zones of magnetization, the AMF was reduced to the equator (RTE - AMF) and then the Total Gradient Amplitude (TGA - RTE - AMF) (Nabighian 1972; Roest et al. 1992; Li 2006) and the Total Horizontal Gradient Amplitude (THDR - RTE - AMF) (Cordell and Grauch 1985) grids were calculated (Fig. 2). Magnetic sources depths estimates were obtained using Standard Euler Deconvolution (SED) (Thompson 1982; Reid et al. 1990). The SED solutions were obtained with structural indexes of 0,1 and 2, window size 20 times the cell size, the maximum error of $10 \%$ in the depth estimate and a flight height of $100 \mathrm{~m}$. The SED solutions were plotted on the THDR - RTE - AMF map and are shown in Figure 3. 


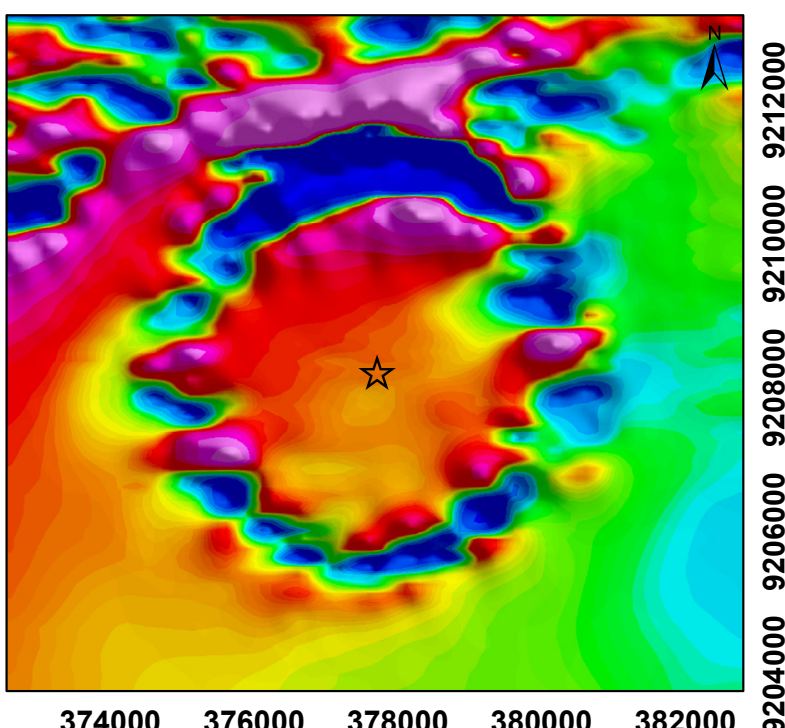

a)
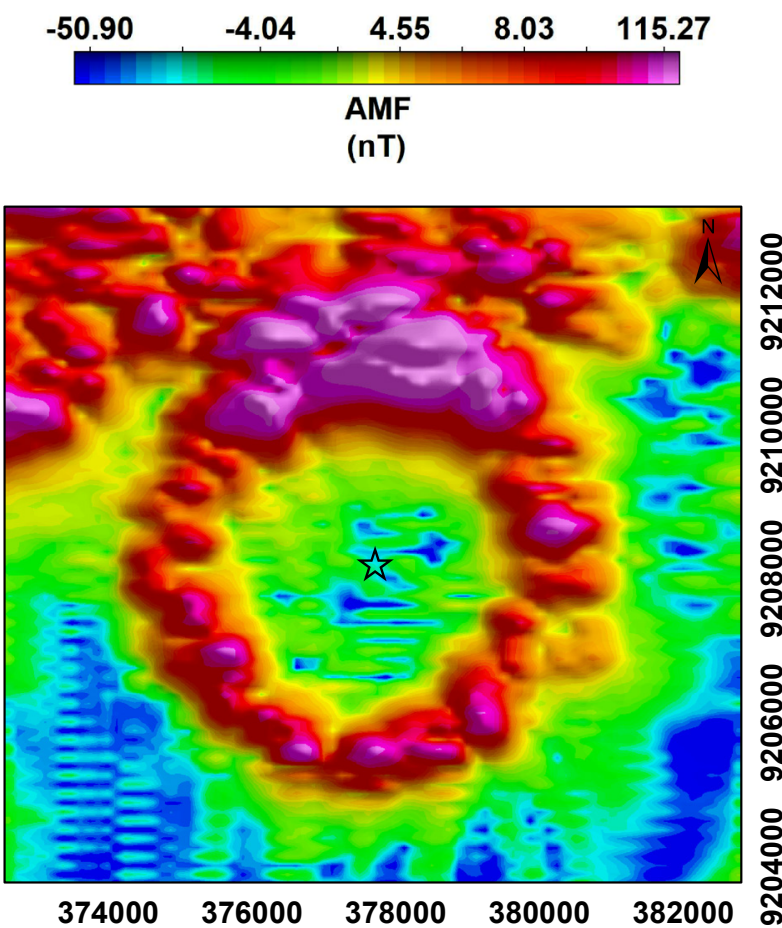

c)

\begin{tabular}{|rrr|}
0.003 & $0.010 \quad 0.062$ & 0.250 \\
\hline $\begin{array}{c}\text { TGA - RTE - AMF } \\
(\mathrm{nT} / \mathrm{m})\end{array}$ & \\
& & 0
\end{tabular}
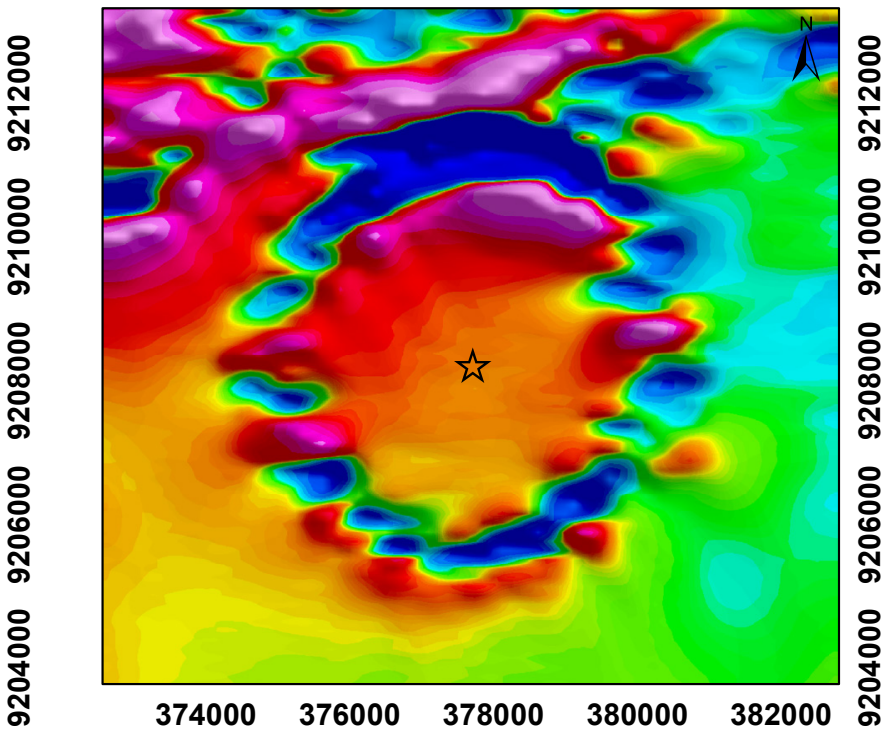

b)
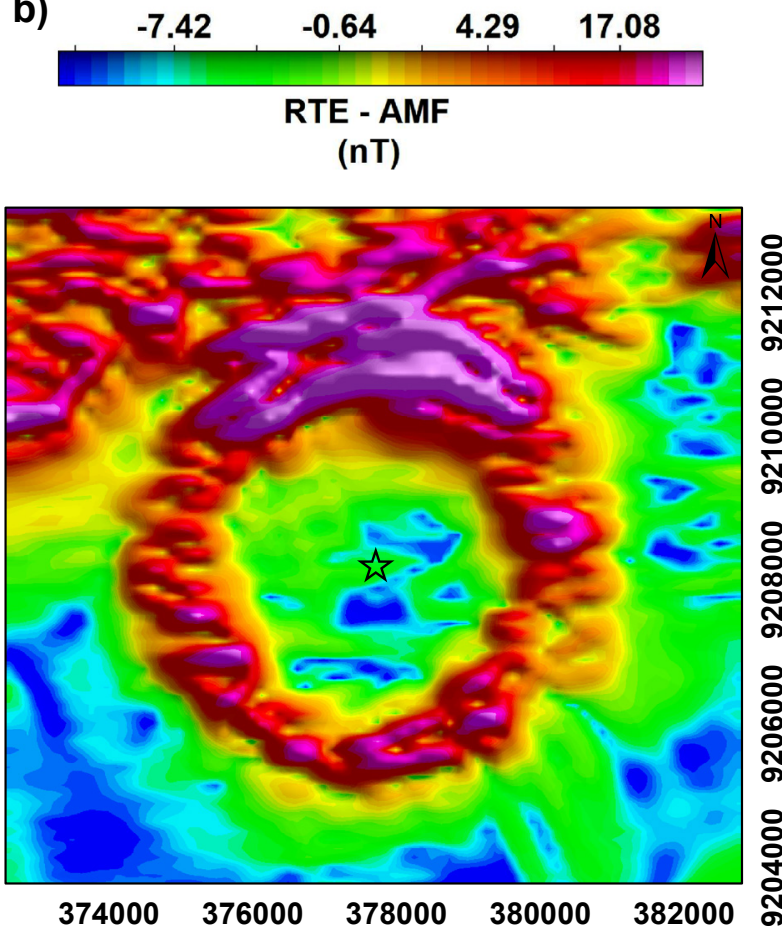

d)

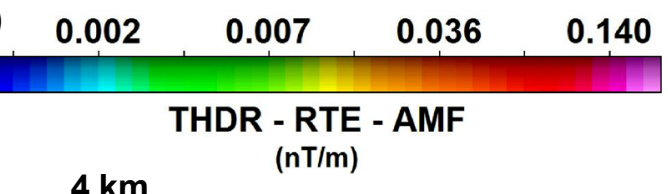

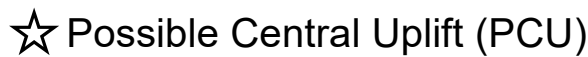

FIGURE 2. Airborne magnetic maps. a) Anomalous Magnetic Field (AMF); b) Anomalous Magnetic Field reduced to the Equator (RTE); c) Total Gradient Amplitude of the RTE (TGA) and; d) Total Horizontal Derivative of the RTE (THDR) 
The airborne gamma-ray spectrometry information was enhanced by calculating radiometric ratios. The procedure of ratios is very useful in highlighting subtle variations of the radioelements. Besides suppressing effects related to the mixture of soil and detector geometry, these ratios provide a measurement of relative enrichment between the radioelements (IAEA 2003). The chosen radiometric ratios were eU/eTh, K/eTh and eU/K. Figure 4 shows the $K$, eTh, and $\mathrm{eU}$ concentration maps and the eU/eTh, K/eTh and eU/K ratios. These maps were superimposed on a shaded relief layer derived from DEM/ALOS PALSAR (see description below) with $45 \%$ transparency.

All grids derived from the airborne geophysical data mentioned above were sampled (125 m spacing) of four databases corresponding to the profiles oriented in $\mathrm{N}-\mathrm{S}$ (P01), NW-SE (P02), NE-SW (P03), and E-W (P04) (Fig. 1). With the aid of the "Seek data" tool integrated with Oasis Montaj software, a DEM derived from the Suttle Radar Topography Mission (SRTM) (30 m spatial resolution) was also sampled (125 m spacing) of the databases profiles aforementioned. The choice of DEM/SRTM topographic data, instead of DEM/ALOS PALSAR (described below), was due to the ease of the DEM from the Seek Data with the local format of the Oasis Montaj software. The profiles P01 - P04 are shown in Figures 5 and 6.

The satellite images analyzed are from the European Space Agency (ESA) Sentinel 2B satellites and a DEM available in a product package with images derived from the Phased Array type L - band Synthetic Aperture Radar (PALSAR) sensor, onboard the Advanced Land Observing Satellite (ALOS).

Sentinel 2B images were collected by the MultiSpectral Instrument sensor (MSI) on 08/31/2019, orbit 081, and tile $23 \mathrm{MLN}$. These images were processed by the Sentinel Ground Segment and have been available on the Copernicus Open Access Hub platform (ESA 2019). Image processing corresponds to the L2A level, which includes radiometric, geometric and atmospheric corrections. The bands are available with the same spatial resolution (ESA 2015). The bands 3, 4, 8A, 11 and 12 with $20 \mathrm{~m}$ spatial resolution were used. Using the Band Rations tool from L3Harris Geospatial's Envi 5.5 software, three sets of images corresponding to the $11 / 8 \mathrm{~A}, 4 / 3$ and 12/11 ratios were produced. These ratios were chosen because Van der Meer et al. (2014) used them to highlight areas enriched with iron oxides, ferruginous silicates, and laterites. However, these ratios were only used to identify areas with different shades and textures. The ratios were

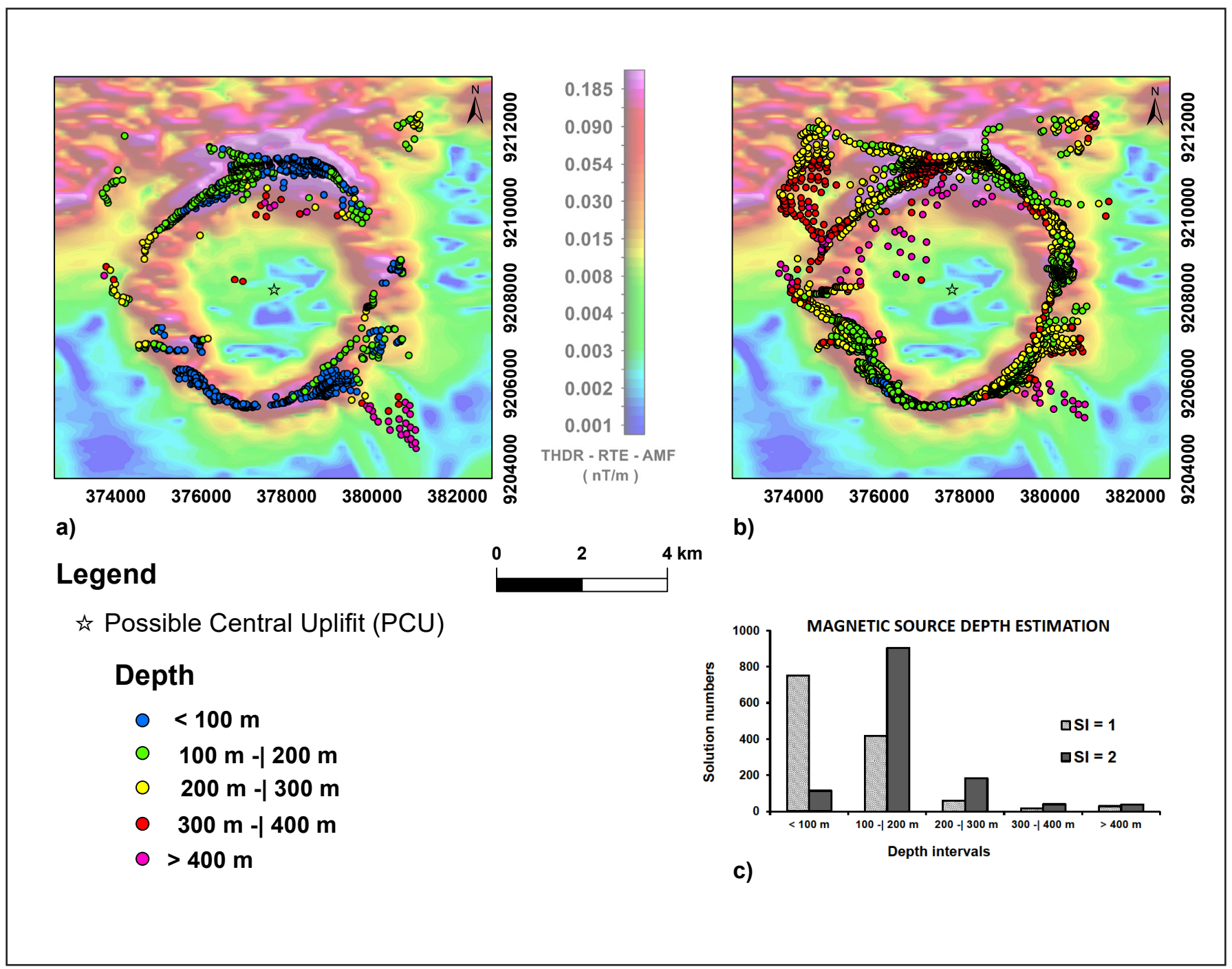

FIGURE 3. THDR map with Standard Euler Deconvolution solutions: a) Solutions with $\mathrm{SI}=1$; b) Solutions with $\mathrm{SI}=2$. c) Euler solutions grouped by depth intervals. 


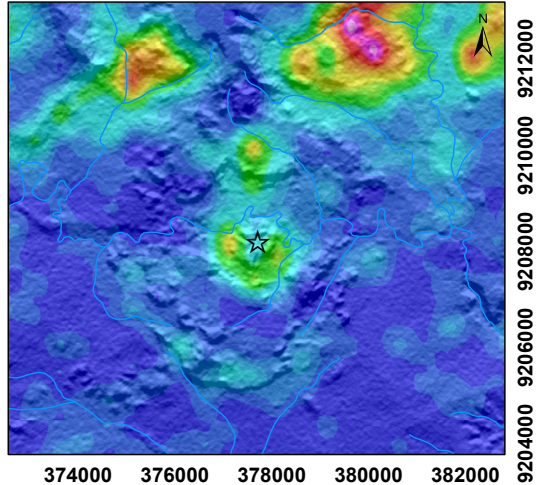

a)
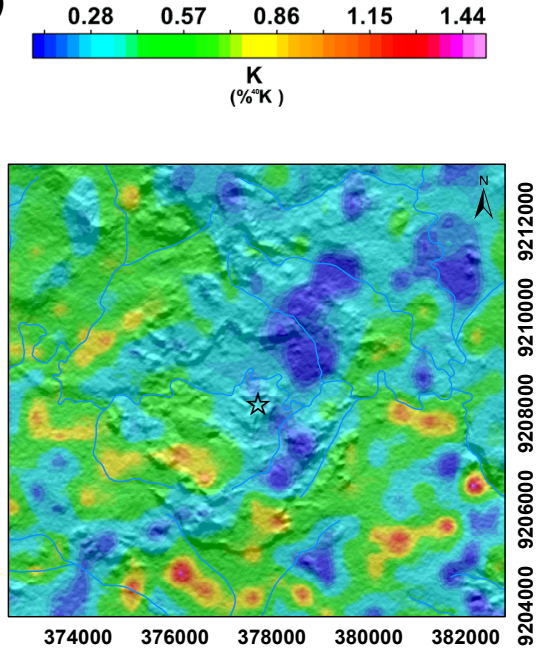

d)

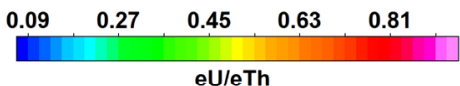

Legend

Rivers and streamlets

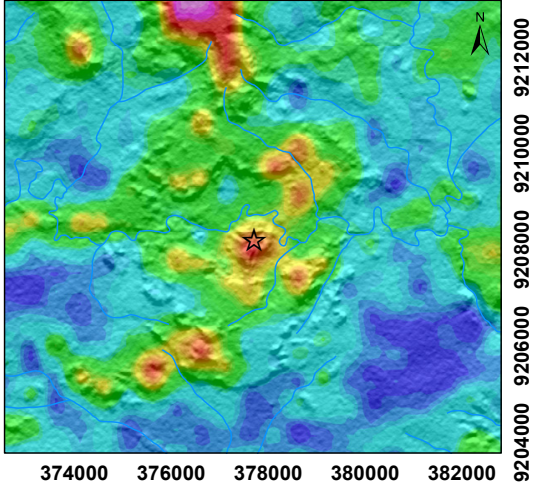

b)
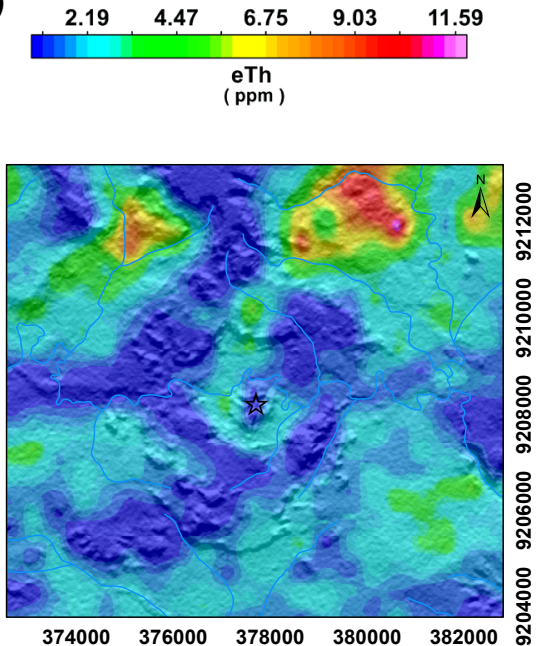

e)
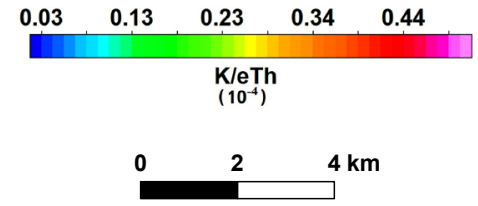

扥 Possible Central Uplift (PCU)

FIGURE 4. Airborne gamma-ray spectrometry maps superimposed on DEM/ALOS PALSAR with $45 \%$ transparency. a) Potassium concentration (measures\% ${ }^{40} \mathrm{~K}$ ); b) $T h$ equivalent concentration ( ${ }^{207} \mathrm{TI}$ measurements); c) Equivalent concentrations of $U$ (measures of $\left.{ }^{214} \mathrm{Bi}\right)$; d) eU/eTh ratio; e) K/eTh ratio; f) eU/K ratio.

combined in $R(11 / 8 \mathrm{~A}), \mathrm{G}(4 / 3), \mathrm{B}(12 / 11)$ to compose a $3 \mathrm{D}$ view map (Figures 7 and 8 ). The 3D view was produced by overlapping the RGB image with a surface derived from DEM/ ALOS PALSAR described below.

The ALOS PALSAR product package is a set of radiometric terrain corrected (RTC package) SAR's images that are processed and made available by the Alaska Satellite Facility's Distributed Active Archive Center (ASF 2007). In addition to the SAR's images, the RTC package includes a reprocessed DEM with $12.5 \mathrm{~m}$ resolution (ASF 2015). The DEM from RTC package used was acquired by Vertex - ASF Data Search platform, on 12/06/2007, orbital 9933, Path Number 52, Frame Number 7040, in Fine Beam Single Polarization mode (ASF 2007). With the aid of the Surface tool from Esri's ArcMap 10.6, a shaded relief map was produced considering a light source with a $45^{\circ}$ elevation and a $0^{\circ}$ azimuth. Similar to the
Sentinel - 2B images, a 3D visualization of the shaded relief was produced by superimposing it with a surface generated by DEM/ALOS PALSAR (Figure 8b).

\section{Results}

From the analysis of airborne geophysical profiles and maps and satellite images produced by using the methodology described in the previous section, it was possible to identify the airborne geophysical responses and landform features described below.

The northern portion of the survey area has a magnetic pattern with a rough texture, while the center - south portion has a gentle magnetic pattern (Figures 2a, 2b). The latter is abruptly interrupted by the presence of a ring-shaped magnetic anomaly. Analyzing the ring-shaped magnetic 


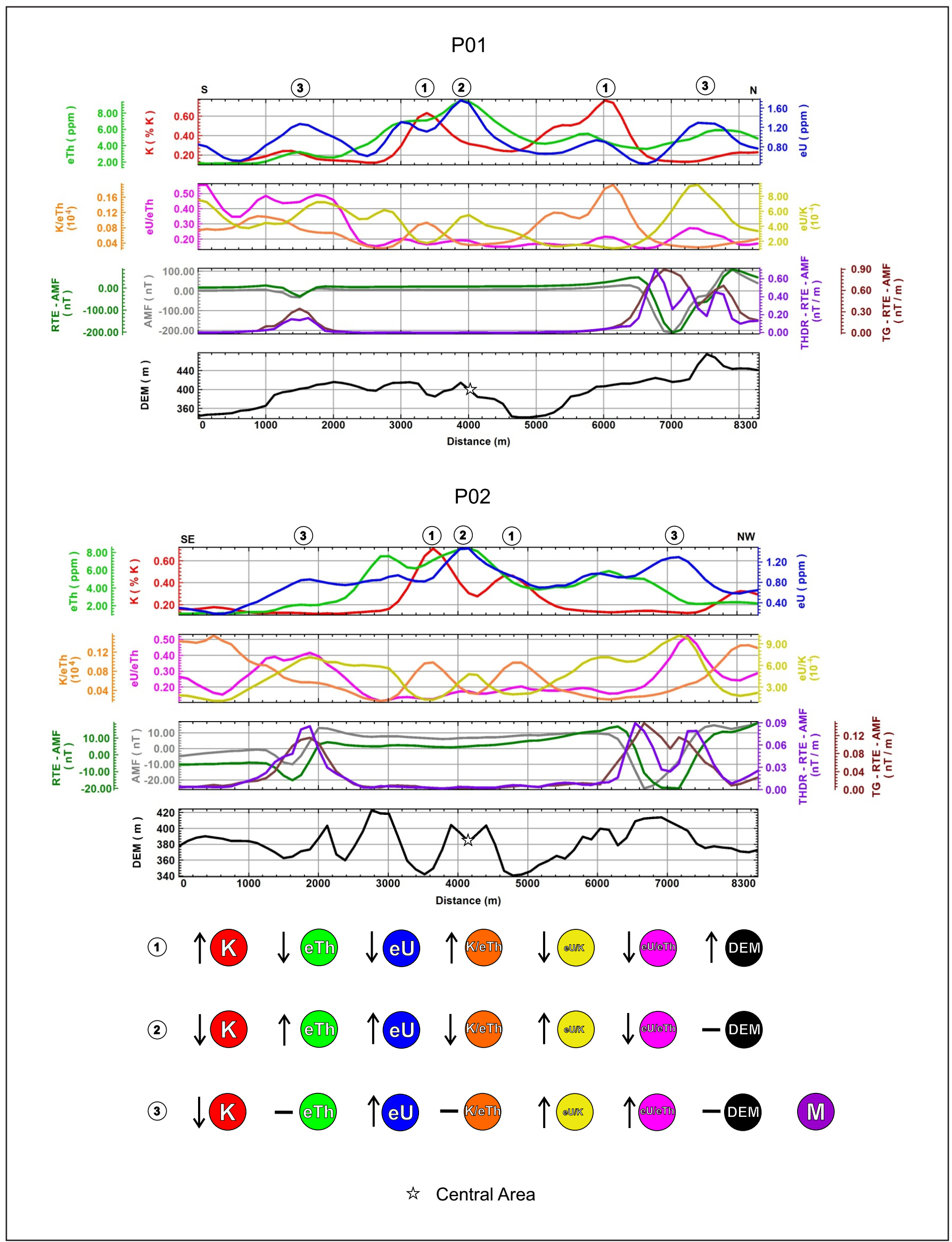

FIGURE 5. Profiles P01 and P02 showing the magnetic and gamma-ray spectrometry responses. Upward, downward arrows and the sign indicate an increase, a decline or invariance in the curves, respectively. The letter $\mathrm{M}$ represents the magnetic anomaly. 
anomaly in the profiles (Figures 5 and 6), the intensity of the magnetic anomaly at profile P01, position $7000 \mathrm{~m}$, is about ten times $(\approx 200 \mathrm{nT})$ greater than the intensity of the magnetic anomalies along all other profiles. In the $7000 \mathrm{~m}$ (P01 and $\mathrm{P} 02$ ) and $1400 \mathrm{~m}$ (P03) positions, the local maximums on the TGA - RTE - AMF curve coincide with local minimums on the THDR - RTE - AMF curve and both are surrounded by two local maximums on the THDR - RTE - AMF curve. In the other positions, however, the peaks of the curves coincide. These shapes suggest differences in the geometry of the magnetic sources present in these positions (Li 2006; Ferreira et al. 2010). Taking the average distance between the two maxima of the TGA - RTE - AMF in each profile, it is estimated that the diameter of the ring-shaped magnetic anomaly is about $5.4 \mathrm{~km}$. The distribution of SED solutions follows the circular shape of the magnetic anomaly (Figure 3). In general, the depths of the magnetic source are concentrated in the first $300 \mathrm{~m}$ (Figure 3c). Depths greater than $300 \mathrm{~m}$ were observed

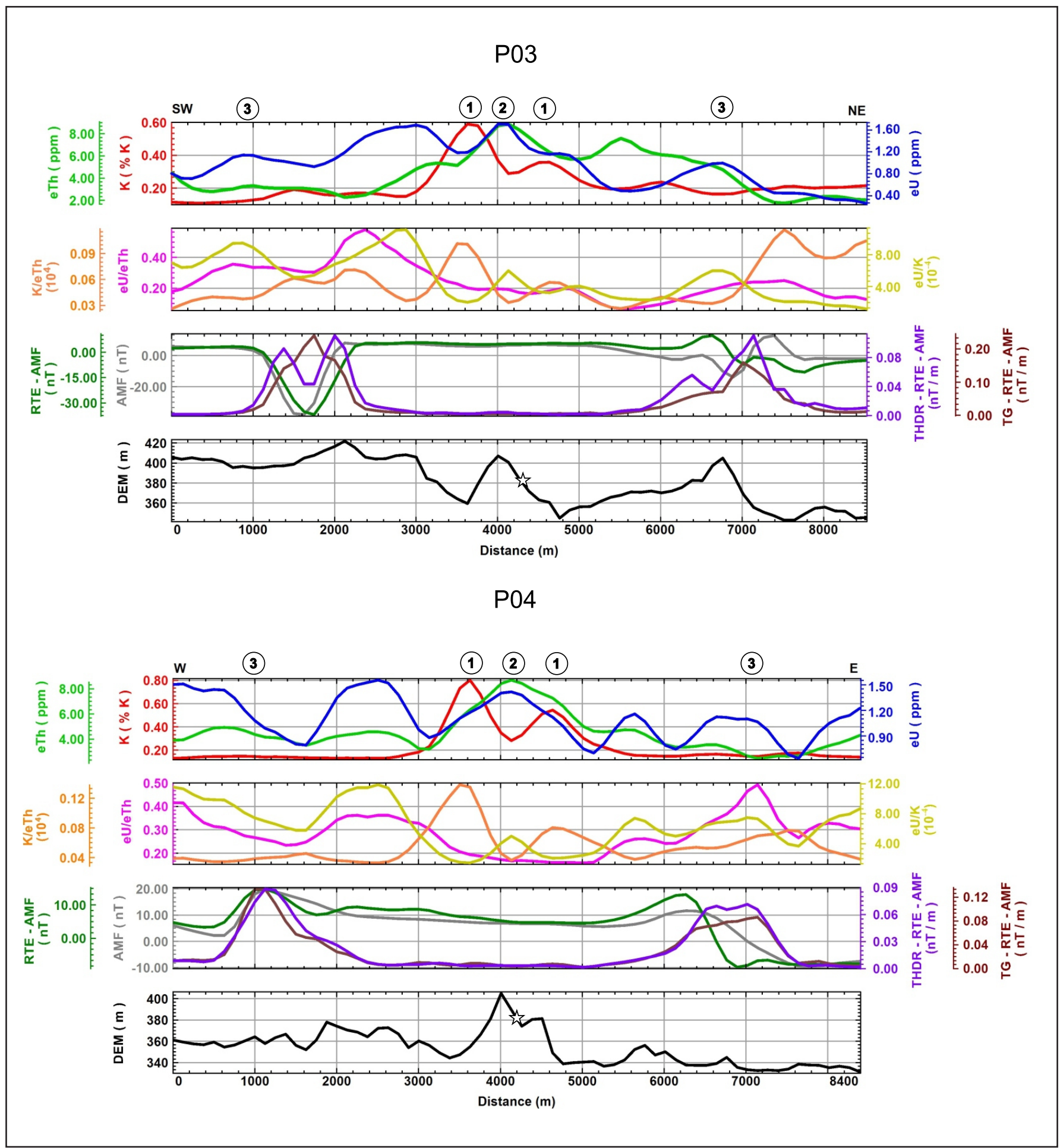

FIGURE 6. Profiles P03 and P04 showing the magnetic and gamma-ray spectrometry responses. The legend is the same as Figure 5. 


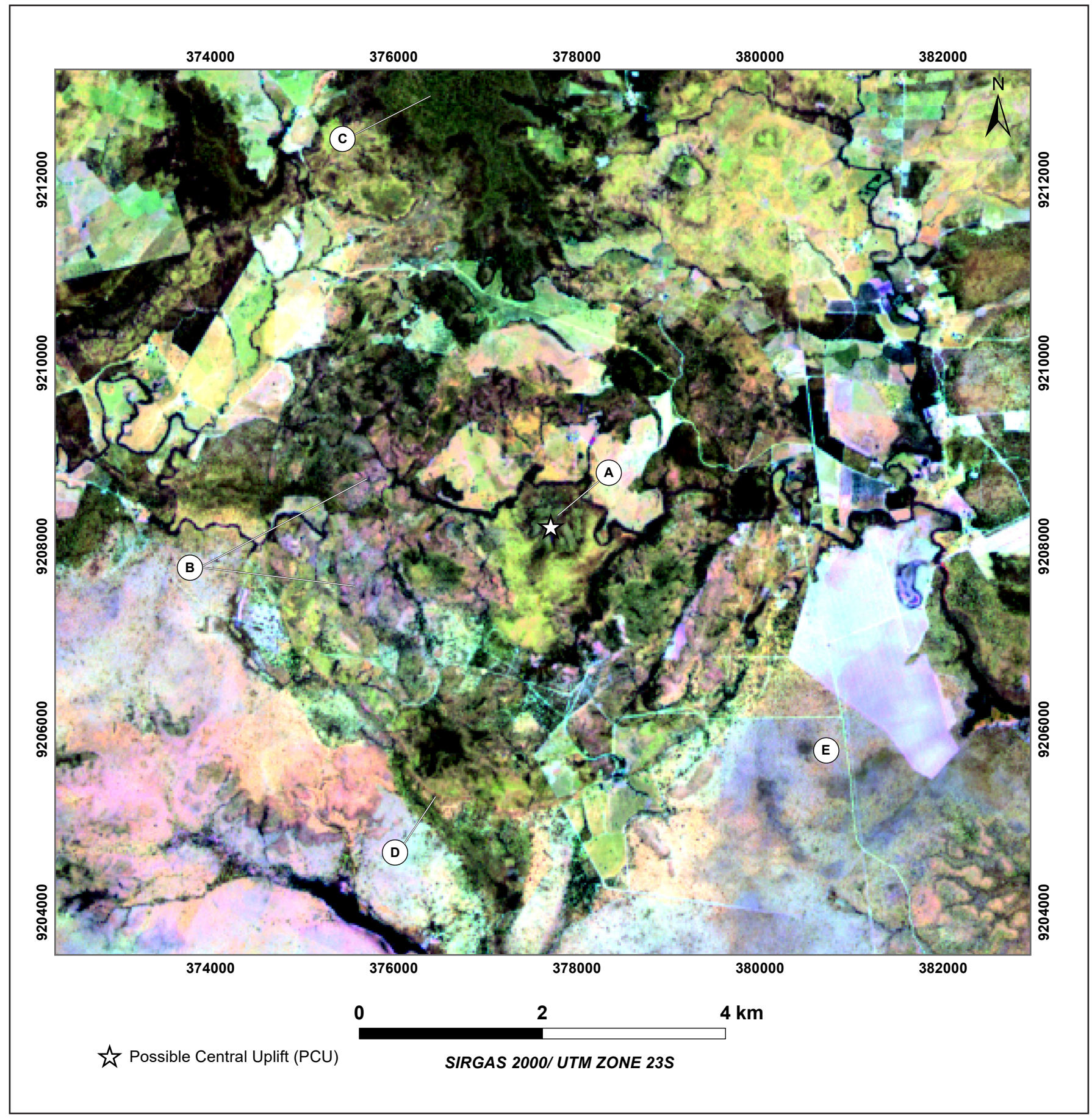

FIGURE 7. Map showing the RGB composition of the 11/8A, 4/3 and 12/11 ratios. The labeled features are described in the text.

both inside and outside the ring-shaped magnetic anomaly. However, such solutions are scattered and have not been considered in the interpretation process. The solutions with IS $=0$ were very scarce and are not presented.

In general, the survey area is characterized by relatively low radiometric signals, with concentration mean values of $0.25 \%, 3.29 \mathrm{ppm}$ and $0.80 \mathrm{ppm}$ for $\mathrm{K}$, eTh and $\mathrm{eU}$, respectively (Figure 4). The eTh and $\mathrm{eU}$ concentrations are relatively higher than that of $K$ at CSS center (CA). On the surround of this center, the opposite occurs: $K$ concentration appears to be relatively higher than of $e T h$ and $e U$ concentrations. Such observations suggest there are distribution patterns of radioelements, which are better observed in profiles.
The analysis of the radioelement concentration and ratios curves in the profiles P01 - P04 reveals at least three behavior patterns listed in 1, 2 and 3 in Figures 5 and 6 . Pattern \# 1 is characterized by an increase in $\mathrm{K}$ concentration in relation to $e T h$ and $e U$ concentrations. This relationship is evident in $\mathrm{K} /$ $e T h$ and $e U / K$ ratio curves, with the first showing an increase and the last showing a decline. The eU/eTh curve remains relatively invariable but at low values. In all profiles, pattern \# 1 occurs on each side of the CA. Regarding to relief, pattern \# 1 occurs where the topography is steep, mainly in profiles $\mathrm{P} 02, \mathrm{P} 03$ and P04.

Pattern \# 2 is characterized by an increase in the $\mathrm{eU}$ and eTh concentration curve and a decline in $K$ concentration 

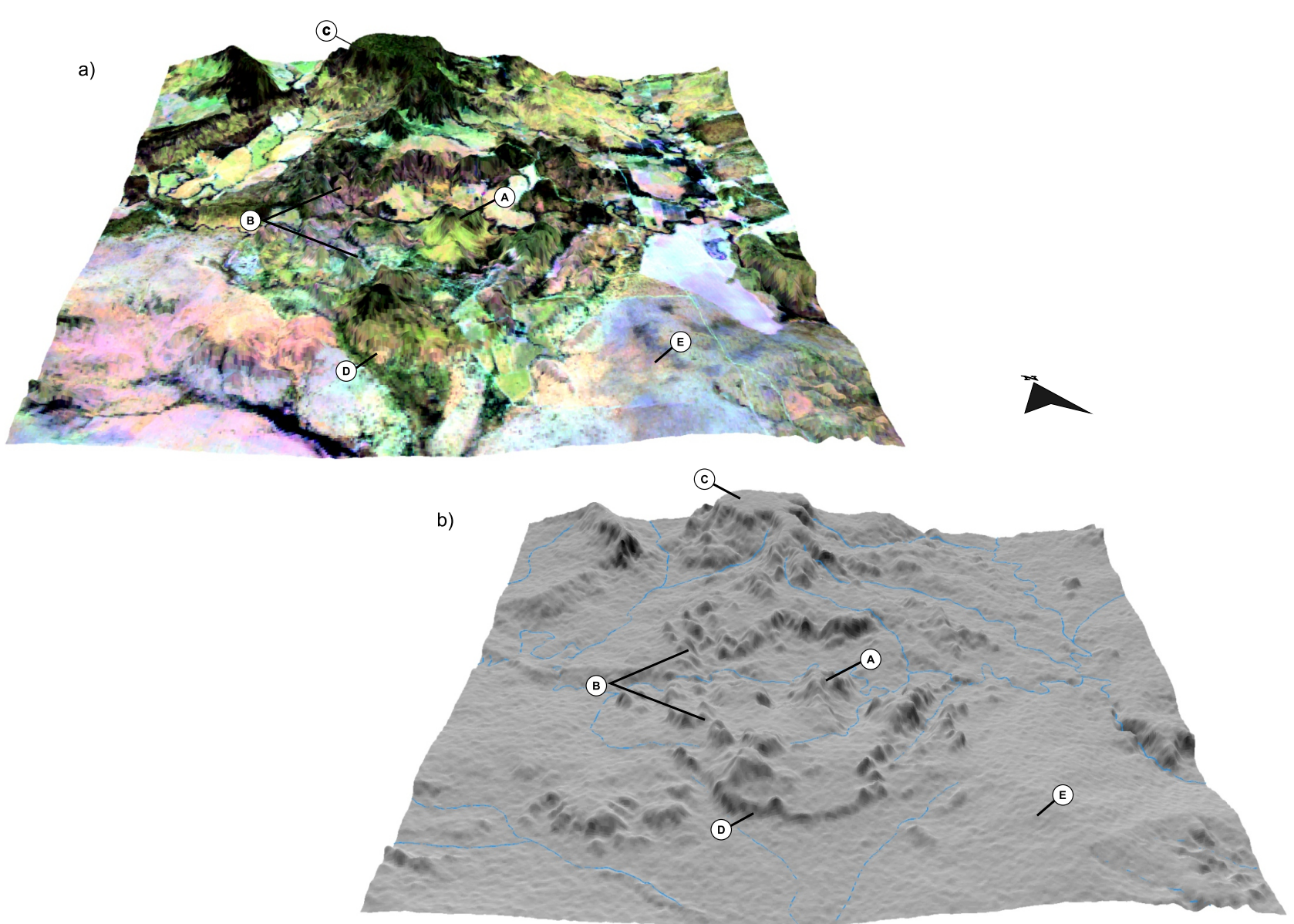

FIGURE 8. 3D view of satellite images. a) Figure 7 images seen in 3D. b) Hillshade DEM. The labeled features are described in the text.

curve. The eU/K and K/eTh ratio curves further highlight the behavior differences of $e U$ and $e T h$ with $K$. Again, the eU/eTh curve remains relatively invariant at low values. The topography seen in pattern \# 2 seems to be less inclined than in pattern \# 1 , however, the gamma-ray spectrometric responses seen in pattern \# 2 coincides with the CA and occurs at topographic levels up to $400 \mathrm{~m}$.

Pattern \# 3 is complex, as some curves (eTh, K/eTh and DEM) exhibit variable behaviors, sometimes increasing, declining, or remaining virtually invariant. However, all profiles show a rise in the $\mathrm{eU}$ concentration curves in pattern \# 3 . Interestingly, in each profile, pattern \# 3 occurs at the ends, being separated by an average distance of $5.9 \mathrm{~km}$. The $K$ curve either declines or remains constant at low levels. Pattern \# 3 is the only one in which the eU/eTh curve shows a significant increase, reaching values almost three times those observed in patterns \# 1 and \# 2.

Regarding the result of processing satellite images, one may view at least five landform features from the satellite images (Figures 7 and 8) named "A", "B", "C", "D", and "E" features. Feature "A" is an elevation with an approximately circular shape and tops with topographic elevations of 400 $\mathrm{m}$ slightly above $(\sim 40 \mathrm{~m})$ the surrounding terrain. The relief shapes "B" seem to be a set of elevations in the inner part of CSS, located mainly in the western and northern portions.
In Figure 7, the pink color represents such elevations with a rough appearance. Feature "C" is a flat-topped elevation with topographic elevations greater than $440 \mathrm{~m}$. Looking at Figure $8 \mathrm{~b}$, the streams in this feature are deflected around the north edge of CSS. In Figures 7 and $8 a$, feature "C" is in dark green color. Feature "D" occurs in the SW portion of CSS, which has a very steep relief and topographic elevations below $400 \mathrm{~m}$. It is interesting to note how feature "D" clearly separates an internal region dominated by wavy relief with a rough texture (feature "B") and an external region, characterized by flat and smooth texture regions (feature "E"). In Figure 7, feature "B" and the western portion of feature $E$ seem to have the same coloring, differing only in the textural pattern.

\section{Discussion}

The results described in the previous section bring out two interesting aspects. The first is the role played by enhancement techniques, which were applied to the data. The TGA and THDR filters applied on the AMF made the ringshaped magnetic anomaly well-defined, while the radiometric ratios enhanced the gentle variations of radioelements and assisted the recognition of radiometric patterns. Furthermore, the relief features have been identified thanks to the range expansion of shades obtained by Sentinel $-2 \mathrm{~B}$ band ratios 
and the illumination angles of the hillshade DEM ALOS PALSAR image. Thus, the use of those techniques enabled the extraction of a larger set of information from the data, which, otherwise, would not be naturally observable at conventional processing. The second aspect is the fact that the findings of this study confirm the morphological features identified in previous works and reveal new similarities that reinforce the suspected origin by impact of CSS.

Among the findings documented here, the ring-shaped magnetic anomaly is the most peculiar. This magnetic anomaly occurs from the magnetization contrast of magnetic sources, which are not seen directly at the surface. Even so, it is possible to infer the nature of the magnetic sources based on information available in published papers.

Based on available geological knowledge, basement highs may be the source of the ring-shaped magnetic anomaly. However, such hypothesis is unlikely to be true, since SED calculated solutions suggest the top of the magnetic sources located at depths less than $300 \mathrm{~m}$, while the depth of the basement top is between $1.5-2.5 \mathrm{~km}$ (Adepelumi et al. 2005; Vasconcelos et al. 2010). In geological maps of the CSS region, structures that can assume circular shapes, such as intrusive bodies or volcanic cones, have not been mapped. Nevertheless, since such maps are in a regional scale, it is possible that such structures may be identified at lower scale mapping. Alternatively, the circular magnetic anomaly of CSS may come from parallel layers of dolerite sills.

When the studied area is observed regionally on a residual AMF map (Fig. 9a), the rugged magnetic pattern observed north of the CSS is the magnetic response of a basaltic swarm (Mosquito Formation), while the smoothed magnetic pattern is due to the weak magnetic response of the eolian sandstones (Sambaíba Formation) (Mocitaiba et al. 2017). However, studies suggest the existence of parallel layers of dolerite sills beyond the SE portion of the CSS (Trosdtorf et al. 2018). In fact, such sill layers are interpreted in a non-migrated seismic section (Ferreira 2013) (Fig. 9b). Although it was not possible to make a direct comparison between the depths of these sills and the SED solutions in the present study, it is possible that the ring-shaped magnetic anomaly sources on CSS may occur due to this parallel layer of dolerite sills.

The sub-horizontal dolerite sills can be the causative source of the ring-shaped magnetic anomaly, but they do not explain the shape of it. The phenomenon that explains this shape is unknown, but it is either endogenous or exogenous origin. The first case may be exemplified by a less magnetic rock (e.g. granitic rock) that intruded the dolerite sill, resulting in a circular magnetic anomaly, which is caused by the magnetization contrast of intrusive rock/dolerite contact zone in the subsurface. The second case may be exemplified by the impact of a solid body, which may have removed or displaced mafic sills, creating the ring-shaped magnetic anomaly similar to Foelsche, Glikson, or Strangways impact structures (MacDonald et al. 2005; Haines and Rawling 2002; Zumsprekel and Bischoff 2005). Regardless of the CSS origin, the magnetic signals from Mosquito Formation basalts may have been superimposed to the ring-shaped magnetic anomaly, resulting in the complex and intense $(\approx 200 \mathrm{nT})$ magnetic anomaly observed northern of CSS at P01 profile. On the other hand, less intensity and simpler shapes of the magnetic signals $(\approx 20 \mathrm{nT})$ at the southern portion may occur exclusively from the sources that have generated the ring- shaped magnetic anomaly, since the surrounding rocks at southern CSS are nonmagnetic.

In spite of the hypothesis of deep sources for the ringshaped magnetic anomaly, the other two findings (radiometric patters and relief shapes) indicate superficial sources for the structure under investigation. In fact, Airborne gammaray spectrometry data provide an estimative of distribution of $K, T h$ and $U$ on the surface. This distribution may predict lithology or soil compositions. Moreover, this distribution may be modified by hydrothermal alteration and/or weathering processes (Dickson and Scott 1997). The satellite images may be used to identify geomorphological elements (Menezes and Almeida 2012) as well as to provide lithology or soil composition information by the mineral spectral signatures. Since the geomorphological process affects the radioelement distribution, a direct relationship between them was already expected (Wilford et al. 1997). From the results described above, it is possible to correlate the \#1 and \#2 radiometric patterns with the geomorphological compartments from feature "A" and radiometric pattern \#3 with the geomorphological compartments from feature " $D$ ".

Feature " $A$ " is an elevated area that coincides with the $\mathrm{CA}$. This area has the top characterized by gamma-ray spectrometric pattern \# 2 (high eTh and $e U$, low $K$ ) and the slope characterized by pattern \# 1 (high $K$, low eTh and $\mathrm{eU})$. The topographic elevation $(\sim 400 \mathrm{~m})$ and the relatively flat relief at the top of feature "A" favors the weathering process, which, in turn, promotes the leaching of $K$ and the concentration of $e T h$ and $e U$. On the other hand, the steep slope of feature "A" favors the erosion process, in a way that the gamma-ray spectrometric response observed in this geomorphological compartment is probably related to fresh rock (Wilford et al. 1997). Based on these observations, the gamma-ray spectrometric pattern \# 2 at the top of feature " $A$ " can be interpreted as a derived weathering effect, while the pattern \# 1 can be interpreted as the radiometric response from lithotypes that have supported the CA. It is possible to infer these lithotypes differ in their composition from the eolian sandstones (Sambaiba Formation), which are composed essentially of quartz (Medeiros et al. 2018).

Radiometric responses have also been reported at central uplifts of known impact structures. High eTh and $e U$ values observed in the Serra da Cangalha central uplift may occur due to a high concentration of zirconium in the shales present at the region, while the high $K$ values observed in Riachão Ring central uplift are probably related to the phyllosilicate cement of Piauí sandstones (Maziviero et al. 2013b apud Crósta et al. 2018; Vasconcelos et al. 2012). The central uplifts of Serra da Cangalha and Riachão Ring impact craters show airborne gamma-ray responses that are distinctive from the surrounding terrain as well as feature "A" in CSS. As suggested by Brenha (2013) and Oliveira (2017), the relief feature "A" may be interpreted as a central uplift, a typical feature of complex impact structures (Grieve 1987), but it is also possible that it may be the result of differential weathering of an intrusion.

According to the available geological information, Mosquito Formation basalts predominate where landform feature "C" occurs, while Sambaíba Formation sandstones are predominant where geomorphological landform features "B", "D", and "E" occur (Aguiar 1971). Feature "C" occurs where the regional relief is characterized by plateaus and residual reliefs formed by differential erosion of the basaltic and sandstones 


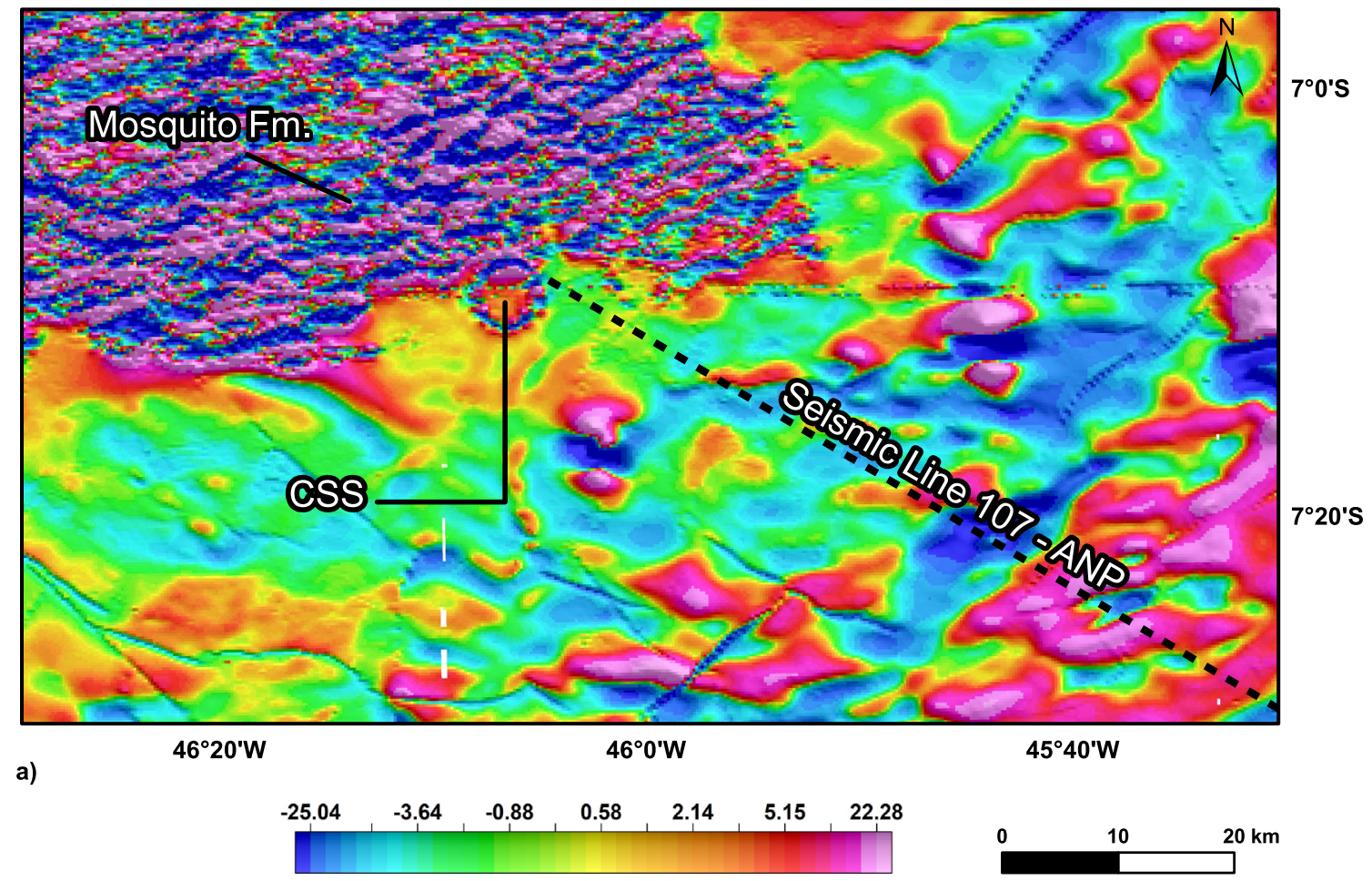

\section{Residual AMF}

(nT)

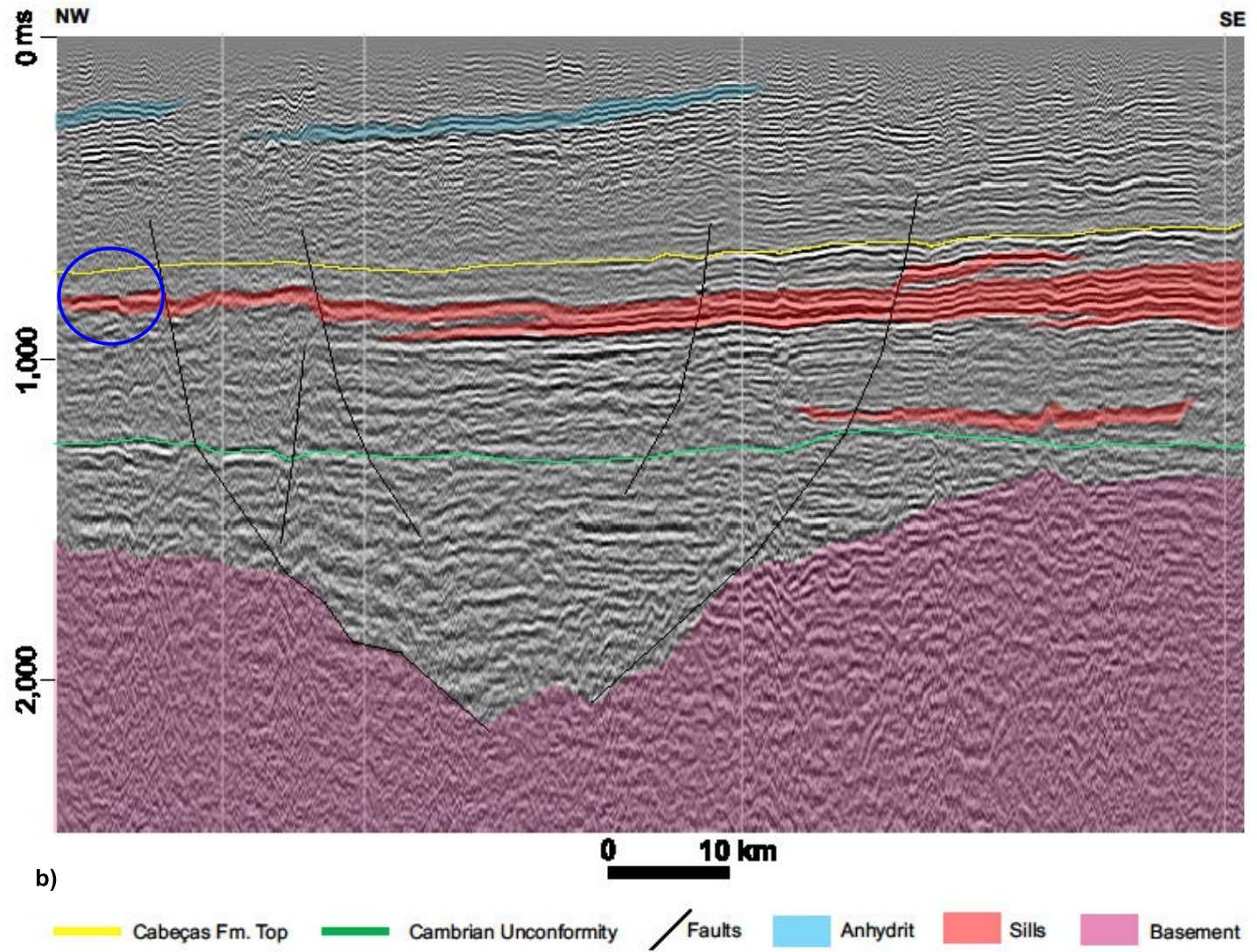

FIGURE 9. Residual anomalous magnetic field (AMF) map of the central part of the Parnaíba Basin, showing the CSS region on a regional scale (a). The residual AMF was obtained by subtracting the original AMF from an AMF continued upwards in 1000 $\mathrm{m}$. Interpreted seismic line 107 (location in Figure 9a - black dashed line), showing extensive sills embedded in sedimentary infill at southeastern CSS (blue circle) (adapted from Ferreira 2013) (b). 
(Lima and Leite 1977). In this way, feature "C" is interpreted as the one that makes up the regional relief. It is interesting to note how the northern edge of CSS deflects watercourses, which come from feature " $\mathrm{C}$ ", suggesting CSS exerts local control over drainage.

Since features "B", "D" and "E" occur in the same lithologic domain, they present similar shades in the "Sentinel 2B RGB" image. The difference between them lies in the physiographic aspect. Feature "B" is internal to CSS, with a wavy relief and rough texture, while feature " $E$ " is external to CSS, with a flat relief and smooth texture. These differences in textures suggest the CSS formation process may have modified the relief pattern, so that the features "B" and "E" represents the affected and unaffected regions, respectively. The limit between these regions is marked by feature " $D$ ".

Feature " $D$ " is geomorphologically similar to an escarpment and corresponds to the south portion of the rim uplifted identified by Oliveira (2017). According to the author, this edge is supported by sandstones (Sambaíba Formation) cut by normal faults. Moreover, this geomorphological compartment is relatively coincident with the location of the radiometric pattern \# 3 (high eU and eU/eTh) and relatively close to the location of the of TGA - RTP - AMF peaks. The average distance between the highs in the $\mathrm{eU}$ profiles seen in pattern \# $3(\sim 5.9 \mathrm{~km})$ is relatively close to the diameter of CSS $(\sim 6$ $\mathrm{km})$, but relatively higher than the diameter of the ring-shaped magnetic anomaly $(\sim 5.4 \mathrm{~km})$. If we consider that feature "D" is supported by Sambaíba Formation eolian sandstones, then it is possible that the maxima in the $\mathrm{eU}$ and eU/eTh profiles is due to the weathering-resistant mineral content (mainly zircon) present in these sandstones (Hollanda et al. 2014). It should also be noted that relief shape " $D$ " is very similar to the outer ring typical of impact crater or volcanic structures.

The circular aspect, presence of normal faults, elevation above terrain surrounding, and correlation with magnetic and radiometric signals are characteristics that have been seen at typical outer rings of the impact craters. As aforementioned, ring-shaped magnetic anomalies from Glikson and CSS structures are very similar. The diameters of these anomalies are relatively smaller than the rim diameters of the structures.

Additionally, high $e T h$ and $e U$ values on Serra da Cangalha rim have been associated with $\mathrm{Fe}$ - oxides from the laterites, while high $K$ values related to deformed strata of Passa Dois Group (siltstone, chert, carbonate, and sandstones) mark the outer edge of Araguainha impact crater (Crósta et al. 2018; Vasconcelos et al. 2012). On the other hand, low radiometric concentrations have been reported at sandstones, which supports the outer rings of Riachão Ring and Strangways impact structures (Maziviero et al. 2013a; Zumsprekel and Bischoff 2005). The observations above enabled the interpretation of feature "D" as a CSS rim, corroborating the exogenous hypothesis origin of CSS. However, the endogenous hypothesis origin of CSS cannot be rejected, because feature " $D$ " is also very similar to a volcanic structure.

From the discussion above, it is possible to observe that CSS shows some similarities with typical features of impact structures. Such similarities are: disruption of the magnetic field by a ring-shaped magnetic anomaly; the presence of central elevation surrounded by a raised outer rim; the local control of drainage and differences in the relief pattern observed in the internal and external parts of CSS. These resemblances reinforce the belief of the CSS origin by impact. However, since these same similarities would result from an endogenous process (e.g. intrusion following by differential weathering), new studies aimed that identifying microscopic and macroscopic characteristics of shock metamorphism are extremely important to confirm or refuse such belief.

\section{Conclusion}

The results presented here, as well as the discussion presented in the previous section, allow us to conclude that the present work has reached its objective regarding the identification of airborne geophysical responses and derived remotely sensed data relief shapes of CSS. The processing techniques used to enhance the images proved to be adequate and eased the recognition of two airborne geophysical responses (ringshaped magnetic anomaly and radiometric patterns) and five relief shapes ("A", "B", "C "," D "and" E "). The 5.4 km diameter ring-shaped magnetic anomaly is well defined and the top of its magnetic sources is about $300 \mathrm{~m}$ deep. The causative body of the magnetic anomaly is unknown, but it is possible that it is due to the circular arrangement of dolerite sill layers.

The radiometric patterns identified seemed to be related to the "A" and "D" landform features. The radiometric pattern \#2 (high $e T h$ and $e U$, low $K$ ) possibly reflects the weathering action on the top of feature "A", while radiometric patterns \#1 (high $K$, low eTh and $e U$ ) and \#3 (increments in the eU curves) would come from lithotypes that have supported "A" and "D" features, respectively. The average distance between the increases in the $e U$ curve seen in pattern \# 3 $(\sim 5.9 \mathrm{~km})$ in each profile is relatively close to the diameter of the CSS ( $6 \mathrm{~km})$; therefore, this pattern may be used as a tool to aid mapping the diameter of the CSS. Features "C" and "E" are outside of CSS. The first is interpreted as a residual relief and the second is interpreted as a flat-relief that is physiographically different from landform observed within CSS (feature "B").

Finally, the disruption of the magnetic field by a ringshaped magnetic anomaly, the presence of central elevation surrounded by a raised outer rim, the local control of drainage and the differences in the relief pattern observed in the internal and external parts of CSS are elements that reinforce the belief of impact origin of CSS. Therefore, new studies aimed at identifying microscopic and macroscopic characteristics of shock metamorphism are extremely important to confirm or refuse such supposition.

\section{Acknowledgments}

The author of this study is grateful to the Brazilian National Agency of Petroleum, Natural Gas and Biofuels and Remote Sensing and Geophysics Division of the Geological Survey of Brazil for providing the airborne geophysical data that were used in this work. The author is also thankful to Andréa de Oliveira (Novo Horizonte Schools), Sérgio Luís Araújo Brenha (Federal University of Maranhão) and Marcos Alberto Rodrigues Vasconcelos (Federal University of Bahia) for providing information that aided the interpretation process presented in this study. Finally, the author is also thankful for JGSB's reviewers by corrections and observations suggested. Such contributions were essential both for this study and my learning. 


\section{References}

Adepelumi A.A., Flexor J.M., Fontes S.L. 2005. Na appraisal of the Serra da Cangalha impact structure using the Euler deconvolution method. Meteoritics \& Planetary Science, 40(8), 1149-1157 1-9. https://doi. org/10.1111/j.1945-5100.2005.tb00180.x

Aguiar G.A. 1971. Revisão geológica da Bacia Paleozoica do Maranhão. In: Congresso Brasileiro de Geologia, 25, São Paulo, Anais. v. 3, 113122

Alaska Satellite Facility (ASF). ASF DAAC 2007, ALOS PALSAR Radiometric_Terrain_Corrected_high_res; Includes Material @ JAXA/ METI 2007. DOI: 10.5067/Z97HFCNKR6VA.

Alaska Satellite Facility (ASF). 2015. ASF radiometrically terrain corrected ALOS PALSAR products. Product guide. Available on line at: https:// asf.alaska.edu/wp-content/uploads/2019/10/rtc product guide v1.2.pdf (accessed on 05 March 2019)

Baski A.K., Archibald D.A. 1997. Mesozoic igneous activity in the Maranhão province, northern Brazil: 40Ar/39Ar evidence for separate episodes of basaltic magmatism. Earth and Planetary Science Letters, 151(3-4), 139-153. https://doi.org/10.1016/S0012-821X(97)81844-4

Brenha S.L.A. 2013. Identificação da cratera meteórica Cabeça de Sapo: Metamorfismo de choque em rochas sedimentares da maior estrutura de impacto do Estado do Maranhão, Nordeste do Brasil. In: Encontro Nacional de Astronomia, 16, Brasília. Available on line at: http:// www.16.enast.com.br/pt-br/16/o-evento/atividades/identificacao-dacratera-meteoritica-cabeca-de-sapo-metamorf/ (accessed on 05 March 2019)

Brito Neves B.B. 2002. Main stage of the development of the sedimentary basins of South America and their relationship with the tectonics of supercontinents. Gondwana Research, 5(1), 175-196. https://doi. org/10.1016/S1342-937X(05)70901-1

Brito Neves B.B., Fuck R.A., Cordani U.G., Thomaz A.F. 1984. Influence of basement structures on the evolution of the major sedimentary basins of Brazil: A case of tectonic heritage. Journal of Geodynamics, 1(3-5), 495-510. https://doi.org/10.1016/0264-3707(84)90021-8

Castro D.L., Bezerra F.H., Fuck R.A., Vidotti R.M. 2016. Geophysical evidence of pre-sag and post-rifting fault reactivation in the Parnaíba basin, Brazil. Solid Earth, 7, 529-548. https://doi.org/10.5194/se-7$\underline{529-2016}$

Cordell L., Grauch V.J.S. 1985. Mapping basement magnetization zones from aeromagnetic data in the San Juan Basin, New Mexico. In: Hinze W.J (ed.). The utility of regional gravity and magnetic anomalies maps. Society of Exploration Geophysicists, 181-197. https://doi. org/10.1190/1.0931830346.ch16

Correia R.T. 2019. Mapa da anomalia radiométrica do Brasil (Terceira edição), Escala 1: 5.000.000. Brasília, SGB - Geological Survey of Brazil. Available on line at: http://geosgb.cprm.gov.br/ (accessed on 10 March 2020).

Crósta A.P., Vasconcelos M.A.R. 2013. Update on the current knowledge of the Brazilian impact craters. In: Lunar and Planetary Science Conference, 44. Abstract \#1318. Lunar and Planetary Institute, Houston, Texas. https://www.lpi.usra.edu/meetings/lpsc2013/ pdf/1318.pdf

Crósta A.P., Reimold W.U., Vasconcelos M.A.R., Hauser N., Oliveira G.J.G., Maziviero M.V., Góes A.M. 2018. Impact cratering: The South American record - Part 1. Geochemistry, 79 (1), 1-61. https://doi org/10.1016/j.chemer.2018.06.001

Cunha M.R., Rocha M.P., Turquetti G.N. 2017. Revealing the rift associated with the Transbrasiliano Lineament at the Parnaiba Basin from seismic reflation data. In: International Congress of the Brazilian Geophysics Society, 15. https://doi.org/10.1190/sbgf2017-146

Daly M.C., Andrade V., Barpusse C.A., Costa R., McDowell K., Piggot N., Poole A.J. 2014. Brasiliano crustal structure and the tectonic setting of the Parnaiba basin of the NE Brazil: Results of a deep seismic reflection profile. Tectonics, 33(11), 2102-2120. https://doi org/10.1002/2014TC003632

Dickson, B.L., Scott, K.M. 1997. Interpretation of aerial gamma-ray surveys adding the geochemical factors. AGSO Journal of Australian Geology \& Geophysics, 17(2), 187-200. Available online at: http:// hdl.handle.net/102.100.100/224930?index=1 (accessed on $10 \mathrm{March}$ 2020)

Dietz R.S., French B.M. 1973. Two probable astroblemes in Brazil. Nature, 244(31), 561-562. https://doi.org/10.1038/244561a0
Earth Impact Database (EID). 2019. Available on line at: http://www passc.net/EarthImpactDatabase/New\%20website 05-2018/Index. html (accessed on 13 March 2020)

European Space Agency (ESA). 2015. Sentinel-2 User Handbook. ESA Standard Document, Issue 1, Rev. 2, ESA, Paris, France, 2015: 64 p. Available on line at: https://earth.esa.int/documents/247904/685211/ Sentinel-2 User Handbook/ (accessed on 13 March 2020)

European Space Agency (ESA). 2019. Copernicus Open Access Hub Rev.122. Available on line at: https://scihub.copernicus.eu/userguide/ (accessed on 13 March 2020)

Ferreira F.J.F., Souza J., Bongiolo A.B.S., Castro L.G., Romeiro M.A.T. 2010. Realce do gradiente horizontal total de anomalias magnéticas usando a inclinação sinal analítico. Parte I - Aplicação a dados sintéticos. In: Simpósio Brasileiro de Geofísica, 4, 1-6. Available on line at: http://www.geologia.ufpr.br/portal/wp-content/uploads/2017/08/ realcehorizontal.pdf (accessed on 15 April 2019).

Ferreira M.A. 2013. Bacia do Parnaíba. In: Seminário Técnico-Ambienta da $12^{a}$ Rodada de Licitações de Petróleo e Gás, 19 setembro, Rio de Janeiro. Available on line at: http://rodadas.anp.gov.br/arquivos/ Round 12/Seminarios R12/apresentacao/r12 04 parnaiba.pdf/ (accessed on 20 November 2019)

Fodor R.V., Sial A.N., Mukasa S.B., McKee E.H. 1990. Petrology, isotope characteristics, and $\mathrm{K}$ - Ar ages of the Maranhão, northern Brazil, Mesozoic basalt province. Contributions to Mineralogy and Petrology, 104, 555-567. https://doi.org/10.1007/BF00306664

Góes A.M.O., Feijó F.J. 1994. Bacia do Parnaíba. Boletim de Geociências da Petrobrás, 8(1), 57-67.

Grieve R.A.F. 1987. Terrestrial impact structures. Annual Review Earth Planetary Sciences, 15, 245-270. https://doi.org/10.1146/annurev. ea.15.050187.001333

Grieve R.A.F., Pesonen L.J. 1992. The terrestrial impact cratering record. Tectonophysics, 216 (1-2), 1-30. https://doi.org/10.1016/00401951(92)90152-V

Haines P.W., Rawlings D. 2002. The Foelsche structure, Northern Territory, Australia: An impact crater of probable Neoproterozoic age. Meteoritic \& Planetary Science, 37, 269-280. https://doi. org/10.1111/j.1945-5100.2002.tb01109.x

Hollanda M.H.B.M., Góes A.M., Silva D.B., Negri F.A. 2014. Proveniência sedimentar dos arenitos da Bacia do Parnaíba (NE do Brasil). Boletim Geociências da Petrobrás, 22(2): 191 - 211.

International Atomic Energy Agency (IAEA). 2003. Guidelines for radioelement mapping using gamma-ray spectrometry data. IAEA, Vienna, Austria, 179 p. Available on line at: https://www.iaea.org/ publications/6746/guidelines-for-radioelement-mapping-usinggamma-ray-spectrometry-data (accessed on 10 March 2020 2020)

Kenkmann T., Vasconcelos M.A.R., Crósta A.P., Reimold W.U. 2011. The complex impact structure Serra da Cangalha, Tocantins State, Brazil. Meteoritics \& Planetary Science, 46(6), 875-889. https://doi. org/10.1111/j.1945-5100.2011.01199.x

Klein E.L., Sousa C.S. 2012. Geologia e recursos minerais do Estado do Maranhão: Sistema de Informações Geográficas - SIG: texto explicativo dos mapas geológico e de recursos minerais do Estado do Maranhão. Escala 1:750. 000. Belém, Serviço Geológico do Brasil - CPRM. Available on line at: http://rigeo.cprm.gov.br/xmlui/handle/ doc/17861?show=full (accessed on 05 March 2019)

Li X. 2006. Understanding 3D analytical signal amplitude. Geophysics, 71(2), L13- L16. https://doi.org/10.1190/1.2184367

Lima E.A.M., Leite J.F. 1977. Projeto estudo global dos recursos minerais da bacia sedimentar do Parnaíba: Integração GeológicaMetalogenética. Recife, CPRM, v. 1., 281 p. Available on line at: http:// rigeo.cprm.gov.br/jspui/handle/doc/9667 (accessed on 20 November 2019)

Marques, R.P., Kassab Jr F., Molina E.C., Andrade F.A.R. (org.) 2006. Levantamentos aerogeofísicos para a identificação de áreas com ocorrência potencial de petróleo e gás na Bacia do Parnaíba - Tomo II: área Parnaíba-Aerolevantamento magnético e gamaespectrométrico, São Paulo, v. I.A, Convênio ANP - USP, 109 p.

Martins J.A., Castelo Branco R.M.G., Castro N.A., Peulvast J.P., Lima Junior S.B. 2016. Morphological analysis of the São Miguel do Tapuio circular structure, Piauí - Brazil. Revista Brasileira de Geomorfologia, 17(4), 763-781. https://doi.org/10.20502/rbg.v17i4.703

Maziviero M.V., Vasconcelos M.A.R., Crósta A.P., Góes A.M., Reimold W.U., Carneiro C.C. 2013a. Geology and impact features of Riachão structure, northern Brazil. Meteoritics \& Planetary Science, 48(10), 2044 - 2058. https://doi.org/10.1111/maps.12213 
Maziviero, M.V., Carrino, T.A., Crósta, A.P., Góes, A.M., Vasconcelos, M.A.R., Reimold, W.U., 2013b. Integrating ASTER, geologic, and airborne gamma-ray spectrometric data as an aid to mapping silica-bearing rocks in the Riachão impact structure, northeastern Brazil. In: Latin American Remote Sensing Week (LARS). Santiago, Chile (abstract).

MacDonald F.A., Wingate M.T.D., Mitchell K. 2005. Geology and age of the Glikson impact structure, Western Australia. Australian Journal of Earth Sciences. 52, 641-651. https://doi.org/10.1080/08120090500170419

Medeiros L.C., Pureza C.G.A., Mayres E.M.M., Lucena G.G.M., Dias L.P., Lima K.P., Abrantes Jr F.R., Rabelo C.E.N. 2018. Petrografia dos arenitos da formação sambaíba, triássico inferior, Bacia do Parnaíba. In: Congresso Brasileiro de Geologia, 49, 1190. Available on line at: http://cbg2018anais.siteoficial.ws/anexos/anais49cbg.pdf (accessed on 30 March 2019).

Menezes P.R., Almeida T. (org.). 2012. Introdução ao processamento de imagens de sensoriamento remoto. University of Brasilia and National Council for Scientific and Technological Development. Brasília, 276 p. Available on line at: http://www.cnpq.br/documents/10157/56b578c4Ofd5-4b9f-b82a-e9693e4f69d8 (accessed on 20 April 2020).

Merle R., Marzoli A., Bertrand H., Reisberg L., Verati C., Zirmmermann C., Chiaradia M., Bellieni G., Ernesto M. 2011. 40Ar/39Ar ages and $\mathrm{Sr}-\mathrm{Nd}-\mathrm{Pb}-\mathrm{Os}$ geochemistry of CAMP tholeiites from Western Maranhão basin (NE Brazil). Lithos, 122(3-4), 137-151. https://doi. org/10.1016/i.lithos.2010.12.010

Mocitaiba L.S.R., Castro D.L., Oliveira D.C. 2017. Cartografia geofísica regional do magmatismo mesocenozoico na Bacia do Parnaíba. Geologia USP, Série Científica, 17(2), 169-192. https://doi. org/10.11606/issn.2316-9095.v17-455

Nabighian M.N. 1972. The analytic signal of two-dimensional magnetic bodies with polygonal cross-section: Its properties and use for automated anomaly interpretation. Geophysics, 37(3), 507-517. https:// doi.org/10.1190/1.1440276

Oliveira A. 2017. Perspectiva do potencial geoparque do astroblema Cabeça de Sapo no município de Novas Colinas - MA. MSc Dissertation, Centro de Ciências Sociais Aplicadas, Universidade Estadual do Maranhão, São Luís, 108 p. Available on line at: http:// www.ppdsr.uema.br/wp-content/uploads/2018/08/andreia-deoliveira.pdf (accessed on 30 March 2019)

Oliveira A.L., Pimentel M.M., Fuck R.A., Oliveira D.C. 2018. Petrology of Jurassic and Cretaceous basaltic formations from with large igneous provinces, In: Daly M.C., Fuck R.A., Julià F., MacDonald I.M., Watts A.B (eds.). Cratonic basin formation: a case study of the Parnaíba Basin of Brazil. Geological Society, London, Special Publication, 472. DOI: https://doi.org/10.6084/m9.figshare.c. 3985437

Oliveira D.C., Mohriak W.U. 2003. Jaibaras trough: an important element in the early tectonic evolution of the Parnaiba interior sag basin, Northern Brazil. Marine and Petroleum Geology, 20(3-4), 351-383. https://doi.org/10.1016/S0264-8172(03)00044-8

Oliveira G.J.G., Vasconcelos M.A.R., Crósta A.P., Reimold W.U., Góes A.M., Kowitz A. 2014. Shatter cones and planar deformation features confirm Santa Marta in Piauí State Brazil, as an impact structure. Meteoritics \& Planetary Science, 49, 1915-1928. https://doi. org/10.1111/maps.12368

Osinski G.R., Pierazzo E. 2013. Impact cratering: processes and products. In: Osinski G.R., Pierazzo E. Impact cratering: Process and Products. 1st. Edition, Blackwell Publishing Ltd., 330. https://doi. org/10.1002/9781118447307.ch1

Pedrosa Jr N.C., Vidotti R.M., Fuck R.A., Castelo Branco R.M.G., Almeida A.R., Silva N.C.V., Braga L.R.C. 2017. Architecture of the intracontinental Jaibaras Rift, Brazil, based on geophysical data.
Journal of South American Earth Science, 74, 27-40. https://doi. org/10.1016/j.jsames.2016.12.012

Reid A.B., Allsop J.M., Granser H., Millett A.J., Somerton I.W. 1990 Magnetic interpretation in three dimensions using Euler deconvolution. Geophysics, 55(1), 80-91. https://doi.org/10.1190/1.1442774

Roest W.R., Verhoef J., Pilkington M. 1992. Magnetic interpretation using the 3-D analytic signal. Geophysics, 57, 116-125. https://doi. org/10.1190/1.1443174

ESA (2015). Sentinel-2 User Handbook; Revision 2; ESA Standard Document; ESA: Paris, France, 2015; 64p

Spisila A.L., Mancini F., Salamuni E., Cury L.F., Romeiro M.A.T. 2014. Análise estrutural da sequência Permiano - Jurássico da Bacia do Parnaíba - região de Araguaína (TO): geometria, cinemática e evolução da deformação. Boletim de Geociências da Petrobrás, 22(2), 237-259.

Soares J.E.P., Stephenson R., Fuck R.A., Lima M.V.A.G., Araújo V.C.M., Lima F.T., Rocha F.A.S., Trindade C.R. 2018. Structure of the crust and upper mantle beneath the Parnaíba Basin, Brazil, from wideangle reflection data, In: Daly M.C., Fuck R.A., Julià J., MacDonald D.I.M., Watts A.B. (eds.). Cratonic Basin Formation: a case study of the Parnaíba Basin of Brazil. Geological Society, London, Special Publication, 472, p. 67-82. https://doi.org/10.1144/SP472.9

Thompson D. T. 1982. EULDPH: A new technique for making computer assisted depth estimates from magnetic data. Geophysics, 47(1), 3137. DOI: https://doi.org/10.1190/1.1441278

Trosdtorf I., Morais Neto J.M., Santos S.F., Portela Filho C.V., Dall Oglio T.A., Galves A.C.M., Silva A.M. 2018. Phanerozoic magmatism in the Parnaíba Basin: characterization of igneous bodies (well logs and 2D seismic sections), geometry, distribution and sill emplacement patters, In: Daly M.C., Fuck R.A., Julià F., MacDonald D.I.M., Watts A.B. Cratonic basin formation: a case study of the Parnaíba Basin of Brazil. Geological Society, London, Special Publication, 472, p. 321340. https://doi.org/10.1144/SP472.10

Van der Meer F.D., Van der Werff H.M.A., Ruitenbeek F.J.A. 2014 Potential of ESA's Sentinel -2 for geological applications. Remote Sensing of Environment, 148, 124-133. https://doi.org/10.1016/j. rse.2014.03.022

Vasconcelos M.A.R., Crósta A.P., Molina E.C., 2010. Geophysical characteristics of four possible impact structures in the Paraiba Basin, Brazil. In: Gibson R.L., Reimold (eds.). Large Meteorite Impacts and Planetary Evolution IV. Geological Society America, Special Paper 465, 201-217. https://doi.org/10.1130/2010.2465(14)

Vasconcelos M.A.R., Leite E.P., Crósta A.P. 2012. Contributions of gamma-ray spectrometry to terrestrial impact crater studies: The example of Serra da Cangalha, northeastern Brazil, Geophysical Research Letters, 39(4). https://doi.org/10.1029/2011GL050525

Vaz P.T., Rezende N.G.A.M., Wanderley Filho J.R., Travassos W.A.S. 2007. Bacia do Parnaíba. Boletim de Geociências da Petrobrás, 15(2), 253-263.

Wilford J.R., Bierwith P. N., Craig M.A. 1997. Application of airborne gamma-ray spectrometry in soil/regolith mapping and applied geomorphology. Journal of Australian Geological \& Geophysical, 17(2), 201-216. Available on line at: https://ecat.ga.gov.au/geonetwork/ srv/eng/catalog.search\#/metadata/81503 (accessed on 05 August 2020)

Zumsprekel H., Bischoff L. 2005. Remote sensing and GIS analyses of the Strangways impact structure, Northern Territory. Australian Journal of Earth Sciences: An International Geoscience Journal of the Geological Society of Australia, 52(4-5), 621-630. http://dx.doi. org/10.1080/08120090500181077 